\title{
“DUALLY EXCEPTIONAL” FAMILIES: SPECIFICS, NEEDS AND PROBLEMS
}

\author{
Otilia Velišek-Braško ${ }^{1}$, ORCID: 0000-0002-9309-7360, \\ Mila Beljanski2*, ORCID: 0000-0002-1545-7949, \\ Nikola Vetnić1, ORCID: 0000-0003-1748-6177

\begin{abstract}
${ }^{1}$ Preschool Teachers Training College Novi Sad, Petra Drapšina 8, Novi Sad, Serbia ${ }^{2}$ University of Novi Sad, Faculty of Education in Sombor, Podgorička 4, Sombor, Serbia

*Corresponding author: Mila Beljanski, mila.beljanski@uns.ac.rs
\end{abstract}

Received: 04.28.2021

Accepted: 05.15.2021

\begin{abstract}
Families blessed with a child with developmental disabilities or a gifted child are not typical families. Such families are exposed to specifics in day-to-day function, establishing interpersonal relationships and fulfilling their family roles. The object of research and studies carried out so far are twice-exceptional individuals, thus excluding the families with one gifted child and another with developmental disabilities. Dually exceptional families have dual challenges in providing additional individualized support for children, in two completely different ways, in two different directions. Based on the results and the analysis of case study of two dually different families, areas in which additional support is required by such families and parents are identified according to family functions, as well as recommendations as to how to empower these areas.
\end{abstract}

Keywords: family, gifted child, child with developmental disabilities, dually different families.

Rezumat. Familiile binecuvântate cu un copil cu dizabilități de dezvoltare sau cu un copil supradotat nu sunt familii tipice. Astfel de familii sunt expuse la specificul unor funcții specifice de zi cu zi, stabilind relații interumane și îndeplinindu-și rolurile familiale. Obiectul cercetărilor și studiilor efectuate până în prezent sunt indivizi de două ori excepționali, excluzând astfel familiile cu un copil supradotat și altul cu dizabilități de dezvoltare. Familiile de excepție au duble provocări în a oferi de zi cu zi sprijin suplimentar individualizat copiilor, în două moduri complet diferite, în două direcții diferite. Pe baza rezultatelor și a analizei studiului de caz a două familii dual diferite, în articol sunt identificate domeniile în care este nevoie de sprijin suplimentar pentru astfel de familii și părinți, precum și recomandări cu privire la modul de abordare a acestor probleme.

Cuvinte cheie: familie, copil supradotat, copil cu dizabilități de dezvoltare, familii dual diferite.

\section{Basic functions of contemporary family}

The understanding of the concept of education in present-day society has, due to current value systems, (our) image of the child and the pedagogical paradigms, necessarily affected the separation of the functions of the modern family, considering that the social context changed throughout history, which eventually led to a change in the role of the 
family. The roles of the modern family are realized through [1] reproductive function - which is reflected in the continuation of the species by means of producing offspring; emotional function - which is the fullest expression of the contemporary family and is completely detached from the reproductive function, it represents the pillar in preserving harmonious family relations and family integrity and is thus the most important function, which affects psychological stability of each family member; economical function - in modern world it is reflected in consumer society, where family income affects its stability; function of providing protection - which encompasses social, moral, legal and economic protection; educational function - considering that education is the right of every child, this function is realized by means of state-implemented systemic solutions, the result of which is the inclusion of children in the educational system, through various forms and levels of education; leisure function - which takes place in different forms, within the family circle but also outside of it, such as outings, vacations, events, meetings, social gatherings. This role implies family members spending quality time together, thus enriching experiences. The specifics of realization of family functions and their combinations depends on priority areas, value systems and family approach, which gives each family its authenticity.

Each family is unique according to structure, dynamics, functioning and life cycle [2]. Family structure is comprised of members, their number and their role within it (father, mother, son, daughter, grandmother, grandfather, other close relatives). Family dynamics are determined by family subsystems, the relations within the same subsystem and those between different subsystems (spouse - spouse, parent - child/children, brother/sister brother/sister i.e. siblings, and the relations with other family members). Different life cycles characterize the family in relation to defining roles within the unit.

\section{Gifted children and their families}

When studying the phenomenon of giftedness, the emphasis is quite often placed on the family of gifted individuals and on how much it can affect the development and expression of child's productive giftedness. Giftedness in children can be detected quite early, especially in areas such as mathematics, music, ballet or chess [3]. However, the giftedness is most often defined as some exceptional ability which, as a rule, is followed by exceptional drive, exceptional motivation to master certain knowledge, skill, rules of a particular domain [4]. Giftedness is the organization of three characteristic properties: above average ability, fulfilling the tasks and creativity [5 - 13]. Therefore, giftedness can, according to today's inclusive concepts, occur in (almost) any domain of human activity, and exceptional achievement in different domains cannot be reduced to just one general intellectual ability [14]. The results referring to IQ alone are considered to be inadequate for determining giftedness, so a multiple identity system is accepted [15]. Determining the different characteristics of gifted students has a major role in creating the program, providing advice and determining the content intended for gifted students. In the literature, the terms giftedness and talent often appear alternately, but talent is generally considered to be an integral part of giftedness [9], i.e. giftedness in one narrow field (academic, artistic, sports talent). Despite the strong, unequivocal genetic influence, the literature $[8,9,16]$ also shows that children's development and the development of giftedness in childhood are greatly influenced by family lifestyles, values, goals and other environmental characteristics. An important role in the growth, development and upbringing of gifted children is played by the parents, i.e. the children's families. Every child affects other children in the family, but because gifted children require so much attention and additional 
strength (resources) they can be the source of added pressure for siblings [17], parents and even other relatives. Parenting is important as well as parenting skills that support optimal talent development, which can be practiced (taught) and nurtured [10] because it is important for parents to be aware of the important role that they play in their child's development in gaining attitudes and beliefs that critically influence talent development. Parents can help in understanding the verbal messages they send, such as encouraging praise and a healthy attitude towards challenges and failure. Because, "with the brilliance of giftedness its shadow grows as well" [18], i.e. the difficulties arise in upbringing, support for learning, encouraging the development of giftedness, but also other life and socioemotional skills in students. Most authors agree that the definitions of adult and child giftedness differ from each other [19] because the criterion of giftedness in adulthood shifts from potential to achievement [20]. High achievement in any field is always associated with high standards set by an adult who himself provides an example of high achievement. Also, when family warmth and care (upbringing) are combined with stimulation and high expectations, an optimal situation is created for the development of talent [21]

\section{Families of children with disabilities}

Within the family, parents are the foundations of the "institution of the family" and the key implementers of family functions. Special understanding needs to be provided to them, especially when it comes to the families of children with disabilities. Support for parents, those who ensure the quality of functioning within it, is of great importance for the entire family and its immediate members [22]. The specific situation, the fact that the child has a diagnosis, sets unique requirements and roles for all family members [1]. Parental knowledge of the fact that their child has developmental disabilities is a powerful event in the family environment. Parents' reactions to the fact that their child is different from other children can be different, because they depend on many factors, but there is a list of "common reactions" created based on parents' feelings, which are: shock, sadness, anger, denial, loneliness and eventually acceptance. The quality of relationships within the family and their construction are of special importance [24], primarily considering the relationship with a child with developmental disabilities, relationships with and between siblings, mutual relationship between partners, as well as relationships with other members of the extended family. Perception and building of the relationship between parents and siblings with the child with developmental disabilities depends on family experiences and the quality of relationships within the family, and less on the severity of the condition of the child with developmental disabilities [10]. Families of children with disabilities are atypical, in terms of internal relationships and dynamics. Such families have specifics and challenges in all roles: reproductive, economic, emotional, protective, educational and leisure role [1]. This affects the stability of the whole family, due to the stated aggravating circumstances that these families have, there is a high probability that the family will become dysfunctional. That is why the role of the state and society, and especially of the educational system is important, as it is up to them to provide all the necessary help and support so that every role is fulfilled and the family is maintained. But in stable, functional and accepting families of children with disabilities, parents and siblings, due to their specificity, strengthen certain characteristics, skills and competencies such as: persistence, resourcefulness, perseverance, patience, but also problem-solving skills, compassion, understanding of the situation and the feelings of others, accepting and respecting diversity, providing support to others $[2,25]$. The path of parents to accepting the fact that 
their child is different from other children is difficult and can even take a long period of time. Understanding of parents and the whole family in the process of coping to acceptance of having a child with disabilities is critical for building an open relationship and cooperation between parents and the main bearers of the institutionalized educational process, i.e. preschool teachers, school teachers and counselors. Cooperation with the family in the period of providing additional support to a child with developmental disabilities, especially during treatments and interventions of special pedagogues (special education teachers, speech therapists...) is crucial, but the approach and attitude towards parents has changed, as well as their role over the years. Different approaches and roles of parents have changes in the process of providing additional support to the child's learning and development and interventions over the last six to seven decades: the parent was seen as a "layman"; then the parents were associates in therapy; afterwards they encouraged and supported "strong mothers"; after that, they noticed partners in parents, and in recent years, parents have become "talent hunters" [26]. Although the trend in the 21st century is to identify talent for certain areas in a child with developmental disabilities, in Serbia and according to the current educational paradigm, partnership with parents is sought and promoted [2]. The partnership and teamwork of experts and parents in providing additional support in children's learning and development is the "formula" that provides the greatest opportunities for the child's progress in order to achieve the child's well-being in all dimensions.

\section{Dually exceptional families}

There are families that are dually exceptional, having one child who is gifted and another child with developmental disabilities. Such dually different families have characteristics of both families with gifted children and families with children with disabilities. The specifics are reflected in the functioning of the whole family, as well as in the realization of family functions, because they have double challenges in providing additional individualized support to their children, in two completely different ways, in two different directions. So far, twice exceptional people and their families $[27,28]$ have been examined and it has been concluded that parents of such children have developed resilient parenting styles within the double exceptionality of their children and at the same time protected their child's talent and advocated for developmental disabilities because they wanted their child to make the most of his or her potential and not be limited by his or her disability. Parents faced challenges in attempt to develop advocacy strategies to manage their child's double exceptionality. However, the topic of dually exceptional families has not been addressed in the literature. The question is raised, what about parents who have one child who is gifted and another with developmental disabilities? What kind of relationships are set up in such, dually exceptional families? How do they manage to reconcile all the tasks and challenges that are set before them? Is there a lack of resources focused on dually exceptional families and their needs? This study deals with the ways in which dually exceptional families function, by noticing their characteristics, as well as the ways of providing additional support to their children, how they support and encourage them in different areas of development in different dimensions and functions.

\section{Research methodology}

The paper presents a double case study, i.e. an attempt to present two families that are dually exceptional. The research used a case study method, a qualitative research that 
uses an interpretive paradigm that seeks to understand the phenomenon in certain, real environments where the researcher does not try to manipulate the phenomenon of interest [24]. The sample of this study is convenient, within arm's reach of researchers, considering the place of contact with families in NGOs. Also, both families live in the same city, though the children attend different schools. As part of the case study in this research, a qualitative approach was appropriately applicable and suitable in understanding in-depth analysis of situations, relationships, and roles within the family. Presented are two dually exceptional families, considering that they both have a gifted child and a child with developmental disabilities. The aim of the research was to notice the specifics of dually exceptional families, to find out what difficulties and challenges they face in achieving family functions, as well as how they manage to respond to very specific and completely different needs for support in their children's education. The sources of information for the study were diverse: parents, siblings, teaching staff, peers, important people in the child's life, as well as the children themselves. Semi-structured interviews were used because they are suitable for this type of research, as they allow flexibility and a more open relationship between researchers and respondents. Moreover, they allow flexibility, which gives greater probability for more detailed answers as well as information about personal experiences of family members. We tried to get closer to the participants' experiences and their subjective constructs, starting from the position that the process of researching personal narratives is a reciprocal process that reduces the distance between researchers and participants.

\section{Research participants}

Two families participated in this study. One family has three children, the oldest child stands out in several areas as gifted, and the middle child has autism, while in the other family the older child is from the autism spectrum, and the younger child is gifted. The age of the children are 12, 14 and 17 in one family, and 13 and 16 in another. Parents also participated in the research, the age of parents ranged from 44 to 51 , as well as head teachers and school teachers, school counselors, classmates and family friends and relatives.

\section{Research instruments}

For the purposes of this research, an interview with open-ended questions was constructed. The questions were: How did the care and upbringing of every child at an early age go? What are the most common emotional reactions in your family? What are the family relationships like (in relation to both adults and children)? What influenced the planning of the number of children in the family? What additional financial costs do you have in providing additional support in learning and encouraging the development of each child? How do you advocate for your children and how do you protect them? How do you achieve educational goals, tasks or requirements? How do you spend your free time with children? What difficulties do you have during family parties, leisure activities and celebrations?

Considering our study is of an exploratory nature, we opted for a qualitative analysis of the collected material. An analytical procedure was used, which is classified as a qualitative thematic analysis, which involves searching for dominant patterns in the collected material [29]. To identify recurring themes in the participants' thoughts, their responses were sorted by similarities and differences. During the analytical procedure, a comparison was made between our categories and the initial responses of the research participants. 


\section{Research results and discussion}

The results of the study show in more detail both families, their structure, members and relationships, while the aim of the study was to find out what difficulties and challenges dually exceptional families face through family functions, how they manage to respond to very specific and completely different needs for support in education of their children.

\section{Review of a case study of the first family with three children}

There are three children aged 17, 14 and 12 in this family, the oldest child stands out in several areas as gifted, and the middle child has autism. The parents are of secondary and higher education and the mother is an expert in the field of education. Both are employed with stable jobs and regular incomes, living in mediocre socio-economic conditions. Children have their own room, but they all share one room, with a special learning space provided for each child. The gifted child stands out in the field of mother tongue, with correct speech and rich vocabulary, can read very expressively, recites extremely well, remembers verses with ease (which he showed at various school performances), excels in spelling and grammar (he also won Republic competitions), and is especially successful in writing various literary forms (he has published texts or parts of texts in newspapers and professional magazines). In addition to being talented in language and literature, the child is extremely successful in the field of computer science, he has participated in student conferences, as well as in national and international competitions, won placements and received various commendations in programming. Another area in which he excels and shows exceptional abilities is fine art, within which he stood out already in preschool age, and his works were sent to various competitions.

The child with developmental disabilities has autism, even at preschool age it was recognized that the child deviates from regular development, he was enrolled in regular school in the first grade, but at the age of 11 instead of subject teaching the transition was made to special school.

The child is verbal, but has difficulties with speech and communication, as well as with mastering school materials. Aided by the personal assistant, he is independent enough to make the trip to and from school along learned routes. With support he also mastered the use of cell phone for short verbal messages with a clear and specific purpose, e.g. to call his parents if he needs help, because the bus broke down and he needs to get off at another bus stop. In addition to school, he attends sports school twice a week, likes functional games, role-playing games and simple board games, and has an extremely small circle of acquaintances, mostly family friends.

Parents point out that it is very difficult and challenging for them to give support to every child (there is also the third youngest child), they admit that it was harder and more stressful for them with a child with developmental disabilities during preschool and at the beginning of elementary school, while with the gifted one it was more challenging and difficult to provide support in learning and meet the specialized educational needs of the child in elementary and secondary school.

\section{Specifics of the first family according to family functions}

\section{Reproductive function}

a. Gifted child: From the beginning of the marriage, they wanted several children. They are proud of their offspring, i.e. of the child's success. 
b. Child with developmental disabilities: They decided to have a third child as well. Concerned about the offspring, i.e. for the future of the child and his care later in life.

II. Emotional function

a. Gifted child: Parents are happy and proud of the child's achievements; they are glad to tell acquaintances of him. "Pride of the family!" Loved and pampered.

b. Child with developmental disabilities: Very much cared for, pampered and loved. Perhaps even overprotected, father in particular does not let anyone hurt his feelings. Expressed tolerance towards him and fewer demands made on him, i.e. indulgence.

III. Protective function

a. Gifted child: He was a victim of peer discrimination and violence in elementary school, precisely because he is gifted, i.e. a "nerd". There was no other systemic service for him.

b. Child with developmental disabilities: Parents use systemic and legal possibilities of social protection, such as childcare subsidy, hiring a personal assistant, transportation tickets and lunch. However, in regular elementary school there were problems in relation to inclusion, individualization of school program and protection from peer violence.

IV. Economic function

a. Gifted child: In elementary and secondary school, he went to additional classes when he was preparing for competitions. He did not attend additional activities outside the education system, except for recreational volleyball for a short period. $\mathrm{He}$ is self-taught, independently learns, reads, works, researches, creates. "He likes to study on his own!" No extra classes or activities were needed, which would even be financially unfeasible, as it is already costly to provide him with a quality computer for work and study. Several times, he received monetary prizes for competition placements from the competition organizers. However, the trips to where the competitions were held cost extra at times.

b. Child with developmental disabilities: Father states that "Financial assistance from the state is welcome, although it could be more." Some of the speech therapy and special education treatments they received through the service support of the state, and periodically they have paid for additional treatments themselves. They used some free activities of the Autism Association (DPOSA) when the child was younger. They regularly pay for recreational sports for nine months a year. These are all additional expenses, as well as the cost of transport (by car or to pay for bus ticket) when someone needs to take him to additional activities. Some activities and treatments could not be afforded such as swimming, horseback riding. In addition, there is a third child who also needs to be provided with and paid for certain activities and interests.

\section{Educational function}

a. Gifted child: It is clear that the child is the "hidden" type of gifted person. Schooling flows smoothly, performs all school tasks independently and in a disciplined manner and masters the contents. He did not have special individualized program, but additional work was done with him in additional classes and sections, and in that way, he was prepared for competitions. 
b. Child with developmental disabilities: The child needs additional support in learning; he attends classes according to adjusted individual educational plan (IEP), due to difficulties in mastering contents that are complex, extensive and abstract. He attended regular kindergarten, as well as regular elementary school, but due to lack of personalized support for learning, demanding tasks and extensive content the inclusion did not succeed. He attends subject classes (as of $5^{\text {th }}$ grade) in a special school with a personal assistant, who was with him for a year. He is making good progress in school, it is easier for him because of learning, but he has little opportunity to interact with his peers, because his classmates are children with extremely severe mental and health conditions, and are thus often absent from school. He is often alone in class with teacher.

\section{Leisure function}

a. Gifted child: The child is quite an introverted type, closed, has only a few close friends. He seldom goes out with his peers. Leisure activities and having fun usually happen within the circle of family and family friends. They rarely go on summer vacations as a family. More often they make smaller family trips. He does not even like taking school field trips, and prefers spending time at home with his family.

b. Child with developmental disabilities: He likes to watch TV shows, cartoons, series, documentaries and movies that are in line with his interests (about animals, cooking...) or those with less complex and abstract content. He has only one close friend, as well as several acquaintances from the group of family friends. Occasionally, accompanied by the youngest brother and family friends, he goes for a walk or a visit, but only in the neighborhood, in the immediate vicinity. He is always invited to birthday parties held by children of family friends, to which he gladly goes.

Based on review of a case of the family with three children, and the specifics of providing support to children through family functions, it is clear that parents recognized the different specifics of their children and in accordance with modest financial resources supported learning and development of each child in an individualized way. In addition, there are particularities in the realization of many family functions, but the function of providing protection is the most pronounced. On the one hand, legal protection (representation) for the child with developmental disabilities is prominent because parents have to be additionally engaged in their realization, which takes a lot of time, which they then do not have to monitor the interests of the gifted child. A gifted child follows his interests quite independently, with greater engagement of parents and experts, the opportunities for potential development would be greater. Poor financial situation leads to the impossibility of participating in specialized programs for gifted children or other occasions (Worrell, 2019), which is the case with this family as well. There is a constant balance and desire to dedicate time to each child, as well as the whole family. The specificity is also expressed in the educational function, which is also an area in which realization is difficult. Specialized residences and centers of interest organized and funded by the state would be a resource that this family would gladly use, if they existed.

A case study of the second family with two children aged 16 and 13, where the older child is from the autism spectrum, and the younger child is gifted. This is an extended family that lives in a spacious house. Each child has their own separate room, as do other family members. Both parents have a university degree, the mother is an educational 
specialist, employed with a permanent income and in good professional positions. The family lives in good socio-economic conditions. They regularly go on vacations and trips, often abroad.

The gifted child stood out as such already as an infant, he was extremely advanced in motor development, he quickly learned by learning from others and via modelling (this is the advantage of younger sibling), he had close interaction with older sibling in preschool, he was very adaptable and cooperative, poised and dedicated. During that period, he showed great interest in the topic of dinosaurs, which he studied and researched in detail. Already in the preschool period, he easily adopted and remembered various contents, data and topics, and he often had leading roles in kindergarten recitals. He was very respectful of the rules and norms of conduct both in the family and in the kindergarten; he was socially popular in the group. He manages schoolwork with ease, he is especially prominent in the fields of natural sciences (mathematics, nature and society), and his interests go beyond school materials or are entirely outside of them (prehistory, prehistoric animals...). Modern teaching methods applied by the class teacher enabled him to get occasional special project tasks in the areas of his interest. He also competed in mathematics, recitation and singing while in class. As far as school subjects are concerned, his dedication, knowledge and success come to prominence in mathematics, physics, chemistry, technical and computer science education, while extracurricular interests are in the field of motoring and cycling, which he studies very thoroughly, in detail and in depth. He participated in competitions in mathematics, physics and chemistry, won placements at the district level, and in addition to his school obligations, he is extremely dedicated and successful in cycling, where he also won medals at competitions.

A child with developmental disabilities has a disorder from the autism spectrum, the so-called Asperger syndrome. Specifics and developmental disabilities were noticed by parents at an early age and a lot of work was done to encourage the child's development at an early age: speech therapy treatments, special education treatments, psychological work with the child, kinesiotherapy, horseback riding, additional swimming activities, dancing, art workshops - all with the great engagement of all family members in providing additional support to the child. He attended regular kindergarten, regular primary school and regular vocational high school, that is, inclusive education is being successfully implemented. The student also has difficulties in establishing social relations, with milder problems of articulation of phonemes and has pronounced difficulties in learning, reading and writing. He masters school content thanks to the readiness of schools to individualize curriculum to meet his needs, to use learning methods and strategies according to his abilities and skills, and with the maximum engagement of parents and other members of the extended family in providing support in learning.

\section{Specifics of the second family according to family functions}

\section{Reproductive function}

a. Gifted child: Great happiness and enthusiasm experienced when he was born. From the get go everything was simpler and easier. Parents worry, that he will have to take care of his sibling for the rest of his life.

b. Child with developmental disabilities: The mother states that "He was 'difficult' to raise, that is, it was difficult to provide care and upbringing for him, he was very demanding, with him everything was exhausting: falling asleep, staying in the yard, 
going to the store..." He was very specific and "fluorescent", a different, demanding child in the preschool period; all of that later changed as he adopted rules of behavior. There are concerns about him, what will become of him, how will he handle the educational system, and how will he handle the difficulties once he grows up. Will he be able to have his own family? Parents wanted three children but gave up on the idea.

\section{Emotional function}

a. Gifted child: Exceptional connection with the child, good understanding and very clear communication, cooperation flows with ease. Proud, enthusiastic parents for the child's success, very supportive. Emotionally, he is a very sensitive child, he requires constant encouragement. He swings from an extremely positive to a very sad and unhappy mood with very pronounced emotional reactions. It is difficult to follow him, due to his changeable mood.

b. Child with developmental disabilities: After going through various emotional phases, parents accept their child, support his interests as well as his development and learning, they are proud of the child's successes and achievements, and at the same time worried about the child's progress and future, mostly because of independence. What makes the situation easier is that the child adopted an extremely positive attitude around age 6-7-8, he is ready to cooperate, very (self)disciplined and quite an obedient child... "He always looks on the bright side!" says his grandmother. He can delight people.

\section{Protective function}

a. Gifted child: There were situations in school when he was rejected in the company of his peers, because he does not do things that typical peers do, as he finds it boring or childish (for example, spraying water in the hallway, running around the classroom...). Besides pride, there is concern about the child's social relations and providing support in establishing relationships with his peers.

b. Child with developmental disabilities: Due to peer violence (mostly psychological), parents, the head teacher, the school counselor and the assistant principal reacted and resolved some critical situations. It is important that problems were always solved. Visiting different services and different sectors in order to exercise the right to social protection is administratively very demanding, e.g. the same requirements should be submitted each year for the bus ticket. "As if it's a cold we're talking about, and the situation can change after a year!" says the father.

\section{Economic function}

a. Gifted child: Additional activities (additional classes, visits, tours, trips...), extracurricular interests are additionally financed, while preparations for competitions for academic knowledge are done in school with additional work with parents. A great commitment to cycling requires extremely large investments from parents (purchase of equipment, training membership fees, participation in competitions...).

b. Child with developmental disabilities: Additional treatments, development incentives and learning support, cost a lot on a monthly basis, because these services are either unavailable (due to them not being present at all) or are insufficiently available through systemic solutions (for example, in the development counseling center, appointments for treatments are given only once a week or every two weeks, which 
is extremely short in the programs of early intervention, because it is necessary to work very intensively at an early age). The invested costs for the child's development and well-being are invaluable, but everything was worth it - said the parents.

\section{Educational function}

a. Gifted child: Very easily masters the regular school content, and in-depth study of areas that are part of extracurricular topics is carried out with support of the family (entire family follows the areas of interest, from dinosaurs to cycling). Of course, the child's self-commitment and self-mastery and study of topics from the available sources of information are expressed (most pronounced are internet searches, TV programs, encyclopedias and of course mentors, coaches and other professionals and peers within the same circle of interest...). Loves to compete, loves to show off his knowledge and skills, he is motivated with prizes, competition placements, medals... (it is safe to say that he is a successful type of a gifted person). Of course, the child's self-commitment and self-mastery, study of topics and with available sources of information are expressed.

b. Child with developmental disabilities: With intensive and constant provision of additional support in learning, in mastering the content and with involvement of several family members (mother, father, grandmother, brother and aunt), due to insufficient independence in learning. The child has most difficulties due to pronounced dyslexia and dysgraphia. Working together, the results in mastering school content are excellent. He likes to learn and good results encourage him.

\section{Leisure function}

a. Gifted child: He attends birthday parties or organized gatherings with his peers, gladly invites friends and acquaintances as guests and likes to organize gatherings at home. He hangs out with children from the neighborhood, goes to the city center, visits theaters, cinemas, parks on his own with friends... He knows how to impose only his own topic of interest, but those topics are not so deeply interesting to other children, and he does not know how to adapt enough to "typical" topics of his peers. That is why he mostly hangs out and is attached to his peers who are in his area of interest (from cycling club). His peers and his interests become a priority over family activities and socializing.

b. Child with developmental disabilities: He follows "trendy" peer topics such as popular computer games, movies and music, so he shares that with a small number of peers. Parents take it upon themselves to initialize and organize the socializing with peers, who are mostly family friends or classmates who attend home celebrations or regular socializing, because they need support in social life. He rarely he goes for walks, visits, to cinema with his brother and some peers... In the family, he likes family activities, rituals and socializing (drinking coffee together, playing cards...).

Based on review of a case of the family with two children, it can be noticed that they face numerous challenges within each family function. According to the data, the realization of the educational function stands out as the most demanding. Parents are extremely committed in this field to respond to completely different support needs in encouraging learning and development. This is recognized in numerous incentive activities and treatments for the child with disabilities and the inclusive approach to his education, as well as in enabling the gifted child to develop his potential and meet specialized 
educational needs in school and extracurricular activities. The realization of the above examples of providing additional support in learning and development for both children is associated with high financial costs and investments, and thus the economic function of the family is burdened. The two dually different families observed are each in their own way special and specific, in terms of the number of family members, internal relationships, priority areas and socio-economic status, but the fact that they both have one gifted and one child with developmental disabilities common for both families. Based on the double case study, it is possible to notice that within each family function in these families there are dual challenges, i.e. a challenge and/or difficulties in one way when the gifted child is concerned, and in another when the other child is in question, and most often that occurs in two separate directions (e.g. with reproductive function there is great pride and vision of success with one child, while at the same time pronounced concern is expressed for the future of the other child). It is also noticeable that the most expressed challenges in fulfilling family roles such families have in the economic and educational role, due to additional financial expenses necessary in order to provide learning support, regardless of whether it is for the sake of encouraging giftedness and specialized educational needs and interests, or it is due to necessity of providing additional learning support for the child with developmental disabilities. What is specific in the reviewed case studies within the educational function is that the focus of the family in the early childhood is on the child with developmental disabilities, which noticeably changes as the parents focus on the gifted child and his success in later schooling, especially in the higher grades.

\section{Study limitations}

Publications and research on "dually exceptional" families are hard to find in national as well as international literature, although such families face dual challenges. In the research of professional and scientific literature and sources, a problem with terminology related to such specific families was noticed, i.e. no adequate expression was established. "Twice exceptional" or "different" $[3,4]$ is a term that refers to children who are gifted and have some kind of learning difficulty, developmental or physical disabilities, but this term is not used in the context of the family. There are numerous studies on families with gifted children, as well as on families of children with disabilities, but not on families where there are both gifted and children with developmental disabilities. Insufficient number or availability of publications on this research topic, as well as terminological doubts about families that are dually exceptional and different are facts that present limitations of this study. Small specimen is another limiting factor, however due to the fact that this is the first such paper in the region; results obtained can be a valuable guideline for conducting and implementation of further research. It would be interesting to examine relationships within such specific families, sibling relationships, as well as division of roles and duties within families.

\section{Conclusion and pedagogical implication}

In this paper, presented are two families that are dually exceptional, that have one gifted and one child with developmental disabilities. The aim of the research was to notice the specifics of dually exceptional families, to find out what difficulties and challenges they face, as well as how they manage to respond to very specific and completely different needs for support in their children's education. Reproductive function is a field where a lot could be done but it is too late for these families. There is a fear of trying to expand the 
family due to exhaustion from additional engagement, but also the issue of caring for the offspring that requires additional engagement (in any direction). If there was a systemic solution for these children who are on the margins (neglected by society and the state), it would certainly be easier for parents to decide on more offspring. Economic and educational function are fields in which systemic solutions would also be important and the family would be somewhat relieved of the concern for children who achieve their potential (in one direction or another) by increased material investment in relation to the regular system. Through additional education, workshops, courses and books the emotional and leisure function could also strengthen capacities of parents, as well as their parental capacities. Also, a break for the family from everyday obligations and activities (for children to attend camps, spend quality and professional time with someone) would rest tired parents and strengthen the quality of mutual relations. The protective function of the family, i.e. being an advocate for one's child, would facilitate good cross-sectoral or transsectoral cooperation of the social system that includes the educational, social and health sectors in order to realize all the rights of every child and provide protection in different sectors.

The parents of the gifted child state that the child is independent in activities, learning at home, that he was offered some programs and activities of his choice, stating that they have more "work" around the child with developmental disabilities. Such a conclusion supports the statement in the literature that the choice of special programs for children with disabilities is much narrower than for children who are gifted [12], and that families of gifted children face the problem of whether to include the gifted child in a program.

The notion of freedom, justice and the pursuit of happiness is a dead letter if gifted education is available only to individuals whose parents can afford it $[29,30]$. It is the responsibility of the state and program creators to make gifted education programs available as well as to help children with disabilities and their families free of charge. Otherwise, such families are torn apart, without the possibility to enable their children to develop their full potential.

\section{References}

1. Velišek-Braško O. Inkluzivna pedagogija [Inclusive pedagogy]. Novi Sad: Graphic i OPEP, 2015.

2. Velišek-Braško O. \& Svilar M. Biti brat ili sestra „drugačijim” osobama [Being a brother or sister to "different" people]. In: Krugovi detinjstva , 2017, 1. pp. 28-38.

3. Stenberg R. J. Giftedness as developing expertise. In K. A. Heler, F. J. Mönks, R. J. Strenberg, \& R. F. Subotnik (Eds.), International handbook of giftedness and talent, 2000, (pp. 55-66). Oxford: Elsevier

4. Altaras A. Darovitost i podbacivanje [Giftedness and failure]. Beograd: Mali Nemo, Institut za psihologiju i društvo psihologa Srbije, 2006.

5. Ferberžer I. Darovitost [Giftedness]. Vršac: Viša škola za obrazvovanje vaspitača, 2002.

6. Foley-Nicpon M., Allmon A., Sieck B. \& Stinson R. D. Empirical investigation of twice-exceptionality: Where have we been and where are we going? In: Gifted Child Quarterly, 2010, 55, pp.3-17. Disponibil: https://doi.org/10.1177/0016986210382575

7. Kaya F., Stough L. \& Juntune J. The effect of poverty on the verbal scores of gifted students, In: Educational Studies, 2016, Disponibil: https://doi.org/10.1080/03055698.2016.1148585

8. Moon S. M., Jurich J. A., \& Feldhusen J. F. Families of gifted children: Cradles of development. In: R. C. Friedman \& K. B. Rogers (Eds.), Talent in context: Historical and social perspectives on giftedness, 1998, (pp. 81-99). American Psychological Association.

9. Olszewski-Kubilius P. Optimal parenting and family environments for talent development. In: M. Neihart, S. I. Pfeiffer, \& T. L. Cross (Eds.), The social and emotional development of gifted children: What do we know? 2016, (pp. 205-215). Prufrock Press Inc. 
10. Orsmond G. \& Fulford D. Adult Siblings Who Have a Brother or Sister with Autism: Between-Family and Within-FamilyVariations in Sibling Relationships.In: Journal of Autism and Developmental Disorders, 2018, Volume 48, Issue 12, pp. 4090 - 4102(13). Disponibil: https://doi.org/10.1007/s10803-018-3669-8

11. Park S., Foley-Nicpon M., Choate A. \& Bolenbaugh M. „Nothing Fits Exactly”: Experiences of Asian American Parents of Twice-Exceptional Children.In: Gifted Child Quarterly, 2018, Volume: 62 issue: 3, pp. 306-319. Disponibil: https://doi.org/10.1177/0016986218758442

12. Reichenberg A. \& Landau E. Families of Gifted Children. In: L.V. Shavinina (ed.), International Handbook on Giftedness, 2009, Disponibil: https://doi.org/10.1007/978-1-4020-6162-2 43

13. Renzulli J. S. The three-ring conception of giftedness: Its implications for understanding nature of innovation. In: L. V. Shavinina (Ed.), The international handbook on innovation, 2003, (pp. 79-96). Amsterdam: Elsevier Science Ltd.

14. Bogosavljević R. \& Beljanski M. Školska pedagogija [School pedagogy]. Sombor: Pedagoški fakultet, 2018.

15. Altun F.,Yazici H. Perfectionism, School Motivation, Learning Styles and Academic Achievement of Gifted and Non-Gifted Students. In: Croatian Journal of Education , 2014, Vol.16; No.4, pp: 1031-1054. Disponibil: https://doi.org/ 10.15516/cje.v16i4.559

16.Zeidner M.\& Mattehew G. Emotional intelligence in gifted students. In: Gifted Education International, 2017, Vol. 33(2) pp. 163-182. Disponibil: https://doi.org/10.1177/0261429417708879

17. Ben-Artzey Schieber N. The gifted child as an equal partner or minority in the sibling relationship: The parents' perspective.In: Child Indicators Research, 2019, 12(6), 2151-2171. Disponibil: https://doi.org/10.1007/s12187-019-09632-8

18. Bagdy E., Kövi ZS. \& Mimisz ZS. A tehetség kibontakozása [The development of talent]. Budapest: Helikon, 2014.

19. Subotnik R.F., Olszewski-Kubilius P. \& Worrell F.C. Rethinking giftedness and gifted education: a proposed direction forward based on psychological science. In: Psychological Science in the Public Interest, 2011, 12, pp. 3-54.

20.Worrell F., Subotnik R., Olszewski-Kubilius P. \& Dixson D. Gifted Students. Annual Review of Psychology, 2019, 70, pp.551-576, Disponibil: https://doi.org/10.1146/annurev-psych-010418-102846

21. Winner E. Darovita djeca: mitovi i stvarnost [Gifted children: myths and realities]. Lekenik: Ostvarenje, 2005.

22. Velišek-Braško O. \& Beljanski M. Uloga roditelja u procesu učenja u inkluzivnom obrazovanju [The role of parents in the learning process in inclusive education], In: Razvojne karakteristike deteta predškolskog uzrasta [Developmental characteristics of a preschool child], 2013, Zbornik radova. Novi Sad: Naučni skup sa međunarodnim učešem, Visoka škola strukovnih studija za obrazovanje vaspitača i Fakultet za sport i turizam, Novi Sad, pp. 9-18.

23.Zaidman-Zait A., Yechezkiely M. \& Regev D. The quality of the relationship between typically developing children and their siblings with and without intellectual disability: Insights from children's drawings.In: Research in Developmental Disabilities. 96, 2020, Disponibil: https://doi.org/10.1016/j.ridd.2019.103537

24. Wu E. Parental Influence on Children's Talent Development: A Case Study With Three Chinese American Families. In: Journal for the Education of the Gifted Vol. 32, No. 1, 2016, pp. 100-129.

25. Velišek-Braško O. \& Svilar M. Dvostruko posebni u inkuziji [Double special in incusion]. Darovitost - potrebe 21. veka. Tematski zbornik radova međunarodnog značaja, 2019, Kruševac: Mensa, pp 85-91.

26. Tamâsnê M. Korai fejlesztés, korai intervenció tapasztalatai [Experiences of early development, early intervention]. Pécs: Apáczai Nevelési és Általános Művelődési Központ, Egységi Pedagógiai Szakszolgálat., 2009.

27. Besnoy K. D., Swoszowski N. C., Newman J. L., Floyd A., Jones P. \& Byme C. The advocacy experiences of parents of elementary age, twice-exceptional children. In: Gifted Child Quarterly, 2015, 59, 108-123. Disponibil: https://doi.org/10.1177/0016986215569275

28. David H. A. Double Label: Learning Disabilities and Emotional Problems among Gifted Children. In: International Letters of Social and Humanistic Sciences. 2017, Vol. 75, pp 22-31. Disponibil: doi:10.18052/www.scipress.com/ILSHS.75.22

29. Creswell W.J. Qualitative inquiry \& research desing: choosing among five approaches. London: Sage, 2007.

30. Davis G., \& Rimm S. Education of the gifted and talented (5th ed.), 2004, Boston: Pearson Education. Disponibil: https://doi.org/10.1037/10297-005 